\title{
The Mediterranean Sepiolidae (Mollusca Cephalopoda) diversity
}

\author{
Giambattista Bello
}

Arion, Via Colombo 34, 70042 Mola di Bari, Italy; e-mail: giamb.bello@gmail.com

\begin{abstract}
Sepiolidae (Mollusca Cephalopoda) is the most diverse cephalopod family in the Mediterranean Sea, where 17 species of this taxon have been identified. In the present review, the updated list of the Mediterranean sepiolids is given along with the species type locality, the first documented record in this basin and the present geographical distribution. The exclusion of Sepiola atlantica and Heteroteuthis atlantis - species that have been reported in the Mediterranean but whose presence is not warranted - from the list is also explained. Moreover, patently erroneous information about the bathymetric and geographical distributions of Sepiola rondeletii is revised. The extreme rarity of Sepiola aurantiaca and the comparatively recent entrance into the Mediterranean and establishment of Stoloteuthis leucoptera are discussed. The genesis of the Mediterranean sepiolid-fauna, in relation to the NE Atlantic fauna, is dealt with and, in particular, the reasons that determined its comparatively broad diversity are examined. They are to be traced back to both the mode of life and reproductive biology of these small-sized cephalopods. In connection with the latter matter, the high degree of endemism in the subfamily Sepiolinae is also explained.
\end{abstract}

KEY WORDS

Cephalopoda; biogeography; biodiversity; Mediterranean; NE Atlantic Ocean.

Received 20.10.2018; accepted 19.01.2019; published online 20.12.2019

Proceedings of the 4th International Congress on Biodiversity "Man, Natural Habitats and Euro-Mediterranean Biodiversity", November 17th-19th, 2017 - Malta

To Adolf Naef (1883-1949) and George Evelyn Hutchinson (1903-1991), perennial sources of inspiration

\section{INTRODUCTION}

Sepiolidae is the most diverse cephalopod family in the Mediterranean Sea, which represents a hot-spot for this taxon since its maximum worldwide richness value was recorded just in this ecoregion (Rui et al., 2019). In all, 17 sepiolid species have been identified in the Mediterranean (Bello,
2008, 2017); all of them are small-sized. They are assigned to three subfamilies, namely Sepiolinae, Rossiinae and Heteroteuthinae, which are distributed worldwide. Members of a fourth, undescribed subfamily were discovered in the Pacific Ocean (Young, 2007).

The present review aims, firstly, at establishing the critical systematic list of the Mediterranean members in this family; secondly, at discussing its biogeography in the north-eastern Atlantic and Mediterranean districts.

To the former aim, the first documented record in this sea is reported for each species and the un- 
warranted, questionable records, both geographically- and depth-wise, are discussed. In fact, the members of Sepiolinae are not promptly identifiable to the species level, especially before their sexual maturation, hence the literature, chiefly the old one, is crowded with many determination mistakes. In this respect, we have to mention that the first scholar to understand the systematics of Sepiolidae, was Adolf Naef (1883-1949). He, when working at the Stazione Zoologica in Naples, revised the whole Mediterranean teuthofauna (Naef, 1923) and described two new genera and seven new species of Sepiolinae (Naef, 1912a, 1912b, 1912c, 1916).

Identification tools for the Mediterranean Sepiolidae are Naef (1923) (a monograph of paramount importance), Mangold \& Boletzky (1987), Guerra (1992) (this also includes NE Atlantic taxa), Bello (1995), Reid \& Jereb (2005) (this is a reference worldwide review that includes the Atlantic species), Bello (2013) (this only relates to the Atlantic-Mediterranean Sepiola atlantica group).

As for the latter aim, the biogeography of the Mediterranean Sepiolidae was discussed by Bello (2003). In the present paper, it is further considered in relation to the NE Atlantic sepiolid-fauna in order to explain the genesis of the Mediterranean sepiolid diversity.

\section{MATERIAL AND METHODS}

This review is based on the relevant literature. In particular, I referred to the "Checklist of the flora and fauna in Italian seas" (Bello, 2008, 2017) for the systematic inventory of the Mediterranean Sepiolidae species, Bello (2015) for their updated nomenclature, and Reid \& Jereb (2005) for their general distribution in both the Mediterranean Sea and the Atlantic Ocean.

Following the critical systematic list of the Mediterranean Sepiolidae, each specific entity is reported with its type locality, first documented Mediterranean record and general distribution. Next, peculiar cases are dealt with: the unwarranted Mediterranean and Atlantic records, the recent entrance into the Mediterranean, and the occurrence in this sea of rare sepiolid species.

\section{RESULTS}

\section{Systematic list of Mediterranean Sepiolidae}

In each subfamily and genus, the type genus and type species, respectively, are reported first, followed by the remaining genera and species arranged in alphabetical order.

Familia SEPIOLIDAE Leach, 1817

Subfamilia SEPIOLINAE Leach, 1817

Sepiola Leach, 1817

Sepiola rondeletii Leach, 1817

Sepiola affinis Naef, 1912

Sepiola aurantiaca Jatta, 1896

Sepiola boletzkyi Bello et Salman, 2015

Sepiola bursadhaesa Bello, 2013

Sepiola intermedia Naef, 1912

Sepiola ligulata Naef, 1912

Sepiola robusta Naef, 1912

Sepiola steenstrupiana Levy, 1912

Rondeletiola Naef, 1921

Rondeletiola minor (Naef, 1912)

Sepietta Naef, 1912

Sepietta oweniana (d'Orbigny in Férussac et d'Orbigny, 1841)

Sepietta neglecta Naef, 1916

Sepietta obscura Naef, 1916

Subfamilia HETEROTEUTHINAE Appellöf, 1898

Heteroteuthis Gray, 1849

Heteroteuthis dispar (Rüppell, 1844)

Stoloteuthis Verrill, 1881

Stoloteuthis leucoptera (Verrill, 1878)

Subfamilia ROSSIINAE Appellöf, 1898

Rossia Owen, 1835

Rossia macrosoma (delle Chiaje, 1830)

Neorossia Boletzky, 1971

Neorossia caroli (Joubin, 1902)

The Mediterranean Sepiolidae

\section{Sepiolinae}

The nominotypical subfamily, Sepiolinae, is the best-defined taxon in this family. In addition to 


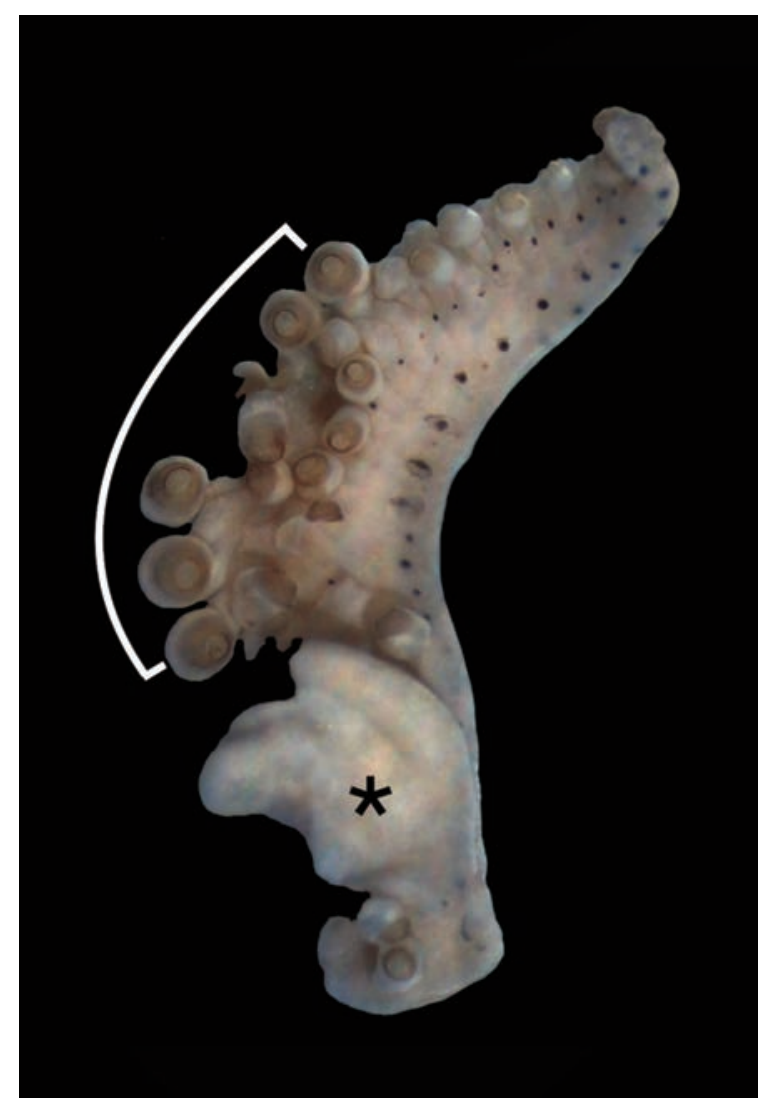

Figure 1. Hectocotylus of Sepiola boletzkyi. The left dorsal arm of Sepiolinae bears modified suckers: the asterisk * marks a group of suckerless lengthened stalks, the white line points out several enlarged suckers in the dorsal row.

other features, it is characterized by peculiar copulatory organs: the hectocotylus in males, i.e. the left dorsal arm modified to transfer spermatophores to females (Fig. 1) and the bursa copulatrix in females, placed in the left ventral mantle cavity (Fig. 2). The latter is an apomorphic character, a unique feature of Sepiolinae. This taxon contains the genera Sepiola (type genus), Euprymna, Inioteuthis, Rondeletiola and Sepietta. Euprymna and Inioteuthis are exclusively Indo-Pacific. Members of this taxon are mainly benthic.

\section{Sepiola rondeletii}

TYPE LOCALITy. "European sea” (Leach, 1817); corrected type locality: Mediterranean Sea (Sweeney, 2001; Bello, 2015). First Mediterranean documented record: Naef (1912a). Note that almost all European sepioline species were ascribed to the

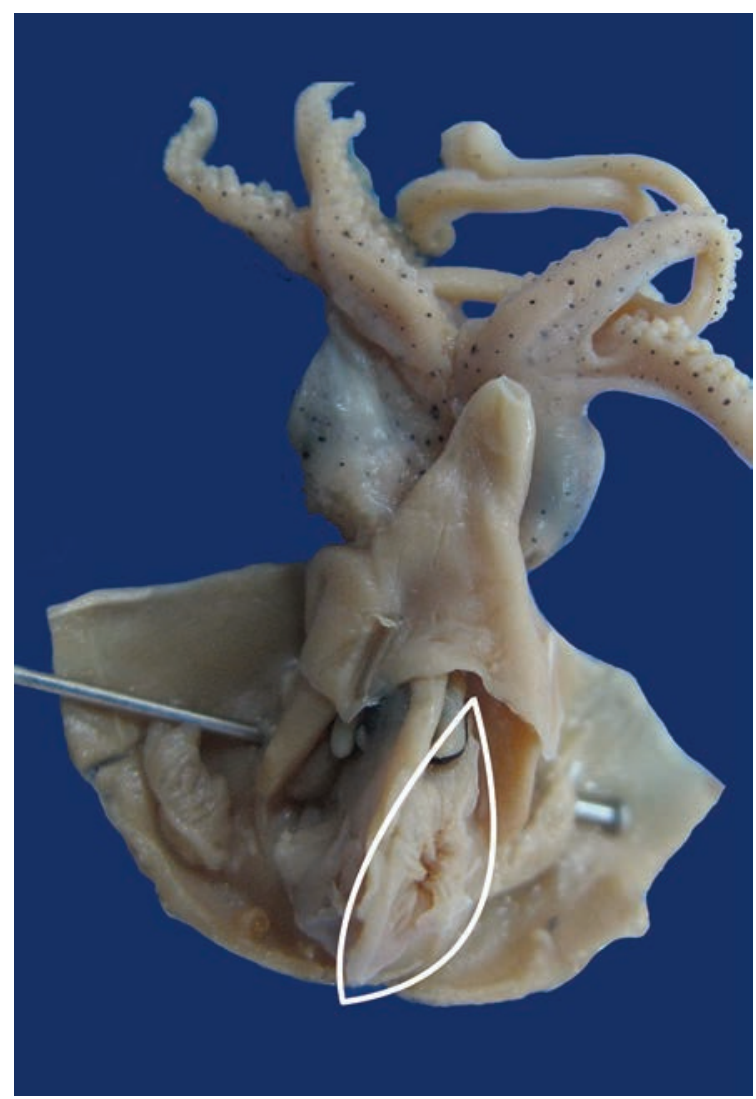

Figure 2. Visceral organs of a female Sepiola boletzky. The white line encompasses the bursa copulatrix, which is the terminal part of the gonoduct; on it the male implants its spermatophores during copulation.

nominal species Sepiola rondeletii before the revision by Naef (1912a) (see further), so that it is virtually impossible to validate all records of this sepioline published before Naef's works (1912a, 1912b, 1923), unless supported by museum specimens and/or well-defined illustrations. Naef (1912a) was the first author to accurately define this species, hence, the first trustworthy identifications are to be credited to him (Bello, 2015).

Distribution And Ecology. It is a quasi-endemic Mediterranean sepioline, which is distributed all over the Mediterranean Sea (Reid \& Jereb, 2005) and in the Atlantic Ocean close to the Strait of Gibraltar, e.g. in the Gulf of Cadiz (Guerra, 1982) (quasi-endemic sensu Bello (2003) is a Mediterranean species that is also found in the Atlantic Ocean in the vicinities of Gibraltar). Although Sepiola rondeletii has been reported in the northeast- 
ern Atlantic Ocean from the North Sea to Senegal (see review by Reid and Jereb, 2005), the northern Atlantic records are inaccurate according to Groenenberg et al. (2009). The typical habitat of this sepioline is "sandy and muddy substrates, common in Posidonia seagrass beds down to $35 \mathrm{~m}$ " (Reid \& Jereb, 2005: 168), however deeper finds, down to $450 \mathrm{~m}$ depth, are reported in the literature (cf. Reid $\&$ Jereb, 2005). In the Gulf of Cadiz, two specimens were collected from a muddy bottom $190 \mathrm{~m}$ deep (Guerra, 1982). See the next chapter "Unwarranted sepiolid records" for geographically- or depth-wise improbable records of Sepiola rondeletii.

\section{Sepiola affinis}

TYPE LOCALITY. Gulf of Naples, Tyrrhenian Sea, western Mediterranean. First Mediterranean documented record: Naef (1912b). It proceeds from the original description.

Distribution AND Ecology. A Mediterranean endemic species. It is a shallow water sepioline that has been reported from the whole coastal belt of the western basin and from the northern coasts of the eastern basin (Reid \& Jereb, 2005), but most probably it also lives along the northern African and Asia Minor shores.

\section{Sepiola aurantiaca}

TYPe LOCALiTy. Gulf of Naples, Tyrrhenian Sea, western Mediterranean. First Mediterranean documented record: Jatta (1896). It proceeds from the original description.

Distribution And Ecology. The only known specimens were collected in the Amontatura (or Ammontatura) channel (100 to $140 \mathrm{~m}$ deep) in the Gulf of Naples.

\section{Sepiola boletzkyi}

TYPE LOCALITY. Gulf of Ildir (Turkey), Aegean Sea, eastern Mediterranean. First Mediterranean documented record: Bello \& Salman (2015). It proceeds from the original description.

Distribution AND ECOLOGY. A shallow water species only known from its type locality.

\section{Sepiola bursadhaesa}

TyPe LOCALITY. Catalan Sea, western Mediterranean. First Mediterranean documented record: Bello (2013). It proceeds from the original description.

Distribution AND ECOlOgy. It is only known from its type locality. It is most probably a shallow water species.

\section{Sepiola intermedia}

TyPE LOCAlity. Gulf of Naples, Tyrrhenian Sea, western Mediterranean. First documented record: Naef (1912a). It proceeds from the original description.

Distribution AND ECology. Sepiola intermedia is a Mediterranean quasi-endemic, since it was also collected in the Gulf of Cadiz (West of Gibraltar) by Guerra (1982). Reid \& Jereb (2005) refer that it is distributed, between 60 and $200 \mathrm{~m}$ of depth, in the whole Mediterranean except the Libyan, Egyptian and Asia Minor coasts. Anyway, most probably it also lives there.

\section{Sepiola ligulata}

TyPe LOCAlity. Gulf of Naples, Tyrrhenian Sea, western Mediterranean. First Mediterranean documented record: Naef (1912a). It proceeds from the original description.

DistriBution AND ECOLOGY. This is a comparatively deep water sepioline, living on muddy bottoms from a few tens of metres down to the upper slope (ca. $350 \mathrm{~m}$ ). It was deemed a Mediterranean quasi-endemic (Bello, 2003) because the northernmost record was that by Guerra (1986) in the Ría de Vigo (NW Spain). The presence of a Sepiola ligulata population in that district was recently corroborated by the collection of paralarvae (OlmosPérez et al., 2017). Indeed, in addition to the whole Mediterranean Sea, it inhabits a wide portion of the NE Atlantic Ocean (de Heij et al., 2017), hence it cannot any longer be termed quasi-endemic.

\section{Sepiola robusta}

TYPE LOCALITY. Gulf of Naples, Tyrrhenian Sea, western Mediterranean. First Mediterranean docu- 
mented record: Naef (1912a). It proceeds from the original description.

Distribution and ECOlogy. An endemic Mediterranean found all over the basin, from a few tens of metres down to $500 \mathrm{~m}$.

\section{Sepiola steenstrupiana}

TyPe LOCALiTY. Off Villefranche (Alpes Maritimes, France), Gulf of Lions, western Mediterranean. First Mediterranean documented record: Levy (1912). It proceeds from the original description.

Distribution AND ECOLOGY. It has been recorded in the northern part of the Mediterranean Sea and in the Levant Sea (Reid \& Jereb, 2005). Outside the Mediterranean, it was collected in the Red Sea (Adam, 1973) and off the eastern Somali coast (Indian Ocean) (Rocha et al., 1998). Accordingly, Sepiola steenstrupiana is an endemic Mediterranean sepioline that seemingly crossed the Suez Canal in a counter-Lessepsian migration.

\section{Rondeletiola minor}

TYPE LOCALity. Gulf of Naples, Tyrrhenian Sea, western Mediterranean. First Mediterranean documented record: Naef (1912a). It proceeds from the original description.

Distribution and Ecology. This is a deepwater East Atlantic-Mediterranean sepioline. Reid \& Jereb (2005) report that it is found from 76 to $496 \mathrm{~m}$ of depth all over the Mediterranean Sea, including the Sea of Marmara, and off the West African and West Iberian coasts, from Namibia to the Gulf of Biscay. A recent survey collected very many specimens farther North to the West of Ireland, and few scattered ones off Scotland and Norway, in a wider depth range, from 25 to $800 \mathrm{~m}$ (de Heij et al., 2017. Rondeletiola minor is one of the most frequently netted sepiolines in the Mediterranean Sea.

\section{Sepietta oweniana}

TYPE LOCALITY. Unknown. This species occurs in both the Mediterranean Sea and the NE Atlantic Ocean. First Mediterranean documented record: Jatta (1896). This author lumped in his description of "Sepiola rondeletii" several sepioline species from the Gulf of Naples, comprising Sepietta spp. too. The pictured elements of the purported Sepiola rondeletii include a hectocotylus (Jatta, 1896: pl. 14 fig. 28) (Fig. 3), which is unmistakably Sepietta oweniana's (compare Jatta's figure to Naef, 1912b: fig. 1, shown in figure 6 of present paper).

Distribution and Ecology. A NE AtlanticMediterranean species from Mauritania to North Norway (Reid \& Jereb, 2005). The occurrence of a specimen farther North, in the SW Barents Sea, is possibly due to the ocean waters warming (Golikov et al., 2014). Sepietta oweniana is distributed over a wide depth range, from few tens of metres to over 1,000 m (Reid \& Jereb, 2005), and is the most abundantly collected Mediterranean sepioline.

\section{Sepietta neglecta}

TYPE LOCALITY. Gulf of Naples, Tyrrhenian Sea, western Mediterranean. First Mediterranean documented record: Naef (1916). It proceeds from the original description.

Distribution AND ECOlOgy. Reid \& Jereb (2005) refer that Sepietta neglecta is found from 25 to $475 \mathrm{~m}$ of depth, in the whole Mediterranean, including the Sea of Marmara, and in the NE Atlantic Ocean from Marocco to the Orkney Islands and South Norway. De Heij et al. (2017) extended its distribution to the waters West of England, Wales and Ireland.

\section{Sepietta obscura}

TyPe LOCALITY. Gulf of Naples, Tyrrhenian Sea, western Mediterranean. First Mediterranean documented record: Naef (1916). It proceeds from the original description.

Distribution and Ecology. A quasi-endemic Mediterranean sepioline that was found in most of the Mediterranean littoral waters and off the West Iberian coast (Reid \& Jereb, 2005). According to the literature data referred by the same Authors, Sepietta obscura depth range is 27 to $376 \mathrm{~m}$. In my opinion, this is a shallow water species that dwells on littoral grounds only, from few metres of depth on (personal observations). 


\section{HETEROTEUTHINAE}

The taxon Heteroteuthinae is indeed polyphyletic (Allcock et al., 2014) and needs a thorough revision. Its members are characterized by a broad web between arms and a comparatively large mantle with extended ventral shield, which characters are indicative of their pelagic mode of life. Some of them display an occipital band, i.e. a dorsal commissure between mantle and head, a feature shared with Sepiolinae, e.g. Heteroteuthis, and others do not, which is typical of Rossiinae, e.g. Stoloteuthis. In addition to the type genus, Heteroteuthis, this subfamily includes Amphorateuthis, Nectoteuthis, Iridoteuthis, Sepiolina, and Stoloteuthis (Young et al., 2015).

\section{Heteroteuthis dispar}

TyPe Locality. Off Messina, Strait of Messina, Mediterranean. First Mediterranean documented record: Ruippell (1844). It proceeds from the original description.

Distribution AND ECology. A mesopelagic species that lives in the whole Mediterranean and the North Atlantic Ocean, down to about 1,600 m of depth (Reid \& Jereb, 2005). It is very abundant and, despite its diminutive size, is a key item in food webs (e.g. Bello, 1999).

\section{Stoloteuthis leucoptera}

TyPE LOCALity. Gulf of Maine, NW Atlantic Ocean. First Mediterranean documented record: Orsi Relini \& Massi (1991), in the Ligurian Sea, western Mediterranean.

Distribution AND ECOLOGY. Jereb \& Reid (2005) refer that it is an amphi-Atlantic species living in the northern West Atlantic Ocean, from Canada to Florida, and from the Bay of Biscay to Namibia in the East Atlantic Ocean; depth range: 160-700 m. It entered the western Mediterranean Sea in recent times and established there a viable population (see further).

\section{ROSSIINAE}

The subfamily Rossiinae contains the largestsized members of the Sepiolidae (up to $10 \mathrm{~cm}$ man- tle length), which are characterized by the absence of both the occipital band and the ventral mantle shield. This subfamily includes the genera Rossia (type genus), Austrorossia, Neorossia, and Semirossia. All rossiines are benthic (Young \& Vecchione, 2014).

\section{Rossia macrosoma}

TYPE LOCALITY. In the surroundings of Naples, Tyrrhenian Sea, western Mediterranean (Bello, 2015). First Mediterranean documented record: delle Chiaje (1830). It proceeds from the original description.

Distribution And Ecology. A North AtlanticMediterranean sepiolid living on comparatively deep grounds, from 25 to $900 \mathrm{~m}$ (Reid \& Jereb, 2005; de Heij et al., 2017). It dwells in the whole Mediterranean basin and in the Atlantic Ocean from Greenland to Norway and far south to Senegal (Reid \& Jereb, 2005).

\section{Neorossia caroli}

Type locality. The Azores, North Atlantic Ocean. First Mediterranean documented record: Dieuzeide (1959), off the Aguelli island (Algeria), south-western Mediterranean.

Distribution And ECology. Neorossia caroli is found in the eastern Atlantic Ocean from Namibia to Iceland (Reid \& Jereb, 2005). According to the review of these Authors, it is a typical upper slope benthic sepiolid recorded down to $1744 \mathrm{~m}$; it has been recorded from neritic grounds as shallow as $40 \mathrm{~m}$, although, in the Mediterranean Sea, the preferred upper limit is at about $400 \mathrm{~m}$ of depth.

\section{Unwarranted sepiolid records}

Adolf Naef, who may be rightly termed the father of modern Teuthology, revised several cephalopod taxa during his stay at the Stazione Zoologica of Naples. He did a most accurate study of Sepiolidae, whose taxonomic situation was quite muddy at that time, and described two new genera and seven new species (Naef, 1912a; $1912 b ; 1916 ; 1921$; 1923). Before Naef's revision, all or almost all European sepioline species were ascribed to the nominal species Sepiola rondeletii 
(cf. Bello, 2015). Hence, all records of "Sepiola rondeletii" prior to 1912 are to be regarded as unwarranted and should not be taken into account. For instance, the drawing of the purported hectocotylus of "Sepiola Rondeleti" presented by Joubin (1902: fig. 2) is evidently copied from Jatta (1896: pl. 14 fig. 28), whose figure, as reported above, depicts the hectocotylus of Sepietta oweniana, a species well established at that time (Fig. 4) (compare Joubin's figure to Jatta, loc. cit.). Also, the arm crown of "Sepiola rondeletii" depicted by Pfeffer (1908: fig. 56) is in fact misidentified: it belongs indeed to Sepiola intermedia, as Naef (1923) already showed; in Pfeffer's partial defence one may say that Sepiola intermedia had not yet been described when he wrote his paper. Sadly enough, even after Naef disclosed and described the Atlantic-Mediterranean diversity in Se- piolinae, many misidentifications have occurred (Bello, 2015). As reported above, in the current literature, the Sepiola rondeletii distribution is reported to cover, in addition to the Mediterranean Sea, the north-eastern Atlantic Ocean from the North Sea to Senegal (see review by Reid \& Jereb, 2005). However, later on, Groenenberg et al. (2009) suggested that the northern Atlantic records are inaccurate. Also, some depth records, as deep as $450 \mathrm{~m}$ (cf. Reid \& Jereb, 2005), are questionable since this sepioline is typically a coastal cephalopod.

As for comparatively recent implausible records, Wurtz et al. (1995) reported a finding of Sepiola atlantica in the South Tyrrhenian Sea, which was not warranted in any way, i.e. no textual description, no photograph, no deposit in any institutional collection. A search for the specimen from

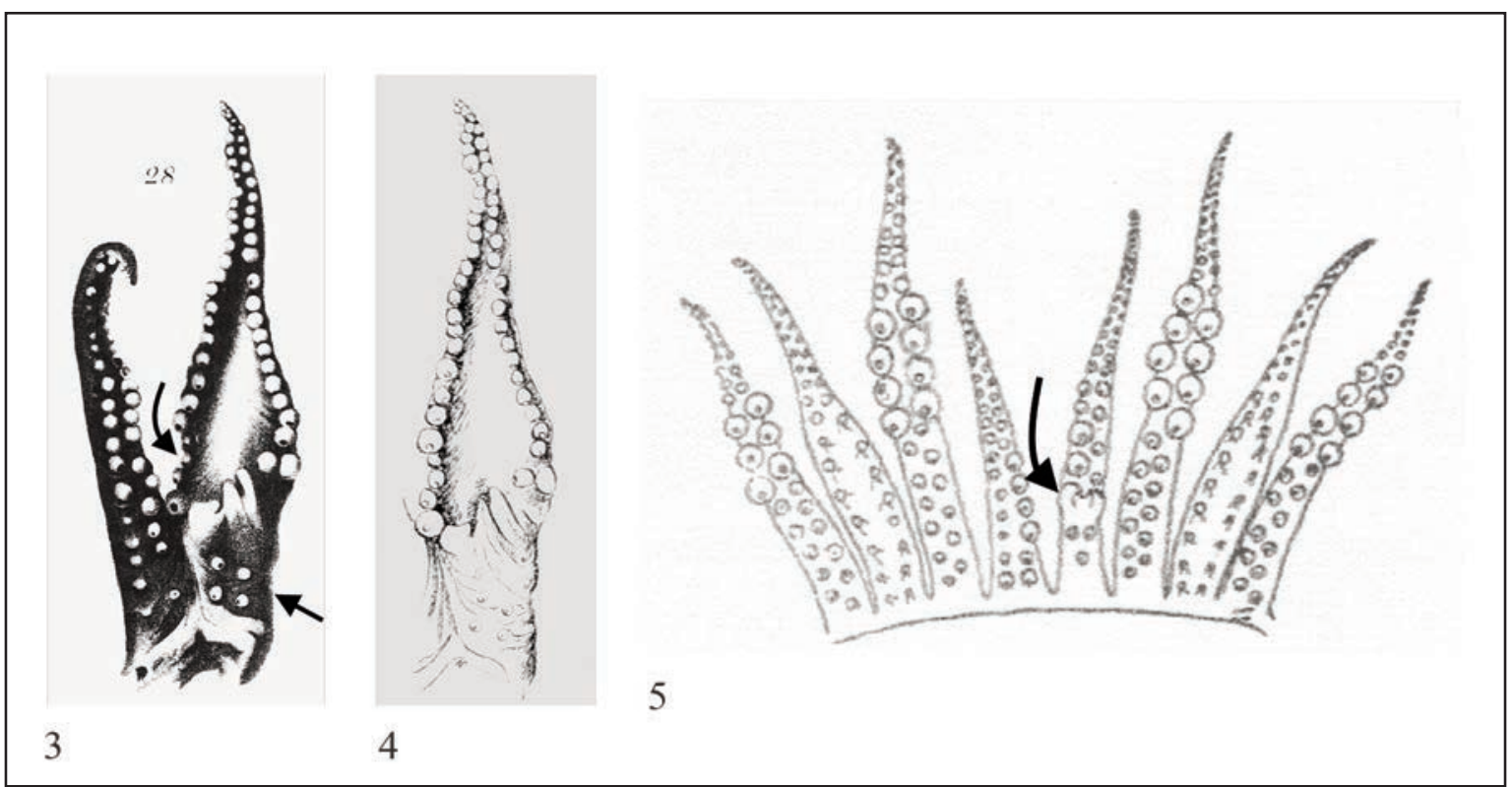

Figure 3. Drawing of the dorsal arms of purported Sepiola rondeletii from Jatta (1896: pl. 14 fig. 28). In fact, the depicted hectocotylus (arm on the right) is typically Sepietta oweniana's according to the four basal suckers (straight arrow) (three in $S$. rondeletii) and the distribution of the enlarged suckers in two groups parted by few smaller suckers (curved arrow) in the dorsal row; the copulatory apparatus is not very indicative of any specific taxon. Compare Jatta's figure to Naef (1912b: fig. 1) (Fig. 6 of present paper), where the actual S. rondeletii and S. oweniana are labelled c and e, respectively.

Figure 4. Drawing of the hectocotylus of purported Sepiola rondeletii from Joubin (1902: fig. 2). This is a copy of a part of Jatta's figure (1896: pl. 14 fig. 28) (see Fig. 3 of present paper) and therefore depicts indeed the hectocotylus of Sepietta oweniana.

Figure 5. Arm crown of "Sepiola rondeletii" depicted by Pfeffer (1908: fig. 56). Naef (1923) stated that this belongs to Sepiola intermedia, according to the distribution of enlarged suckers and despite the fact that the copulatory apparatus (arrow) was inadequately delineated. 
the Tyrrhenian Sea by the present author was unsuccessful. A further negative evidence is the list by Giordano \& Carbonara (1999) which did not report this species among the cephalopods collected in 13 extensive bottom trawl surveys in that sea. In my opinion Würtz et al.'s (1995) record is not be taken into consideration. It was also doubted by Reid \& Jereb (2005) by a question mark in the relevant distribution map.

A Mediterranean finding of Heteroteuthis atlantis was reported in a note of the paper describing the new species (Voss, 1955). Though this binomen was placed into synonymy with Heteroteuthis dispar by Nesis (1987), Heteroteuthis atlantis was subsequently cited, doubtfully yet, among the Mediterranean Sepiolidae (e.g. Bello, 1995). Nesis' (1987) opinion is shared by MolluscaBase (2018). Reid \& Jereb (2005) state that until the taxonomy of the genus is studied, the validity of this heteroteuthine remains questionable.

\section{Recent sepiolid Mediterranean entrance}

Stoloteuthis leucoptera is the only extraMediterranean sepiolid that entered this basin in comparatively recent times. It is an amphi-Atlantic species (Reid \& Jereb, 2005) that was first recorded in the Ligurian Sea thanks to three specimens collected there in 1988 (Orsi Relini \& Massi, 1991) and afterwards was found in other western Mediterranean districts (Volpi et al., 1995; Würtz et al., 1995; Sánchez et al., 1998; Cuccu et al., 2010; Quetglas et al., 2013). The report by Quetglas et al. (2013), who netted 25 specimens mostly in the Alboran Sea, is particularly interesting because they started to capture this sepiolid only in 2001, while no one had been caught in previous surveys, from 1994 to 2010. In my opinion, the many Mediterranean occurrences of this cephalopod from the late ' 80 s on, coupled with the lack of previous records from areas well surveyed in the past, soundly support the hypothesis that Sepiola leucoptera naturally entered the Mediterranean Sea from the Atlantic Ocean through the Straits of Gibraltar, extended its range within the western basin and succeeded in generating a self-sustained population (Battaglia et al., 2011). As for the Alboran Sea, the reported presence of Sepiola leucoptera since 2001 only (Quetglas et al., 2013) may be either due to a further immigration bout or to the westward expan- sion of the recent Mediterranean population. Lastly, heteroteuthines are known to lay their eggs on the sea floor (Nesis, 1993), hence the crossing of the Gibraltar Strait for sure involved juveniles and/or adults rather than early juveniles of this pelagic species.

The Sepiola leucoptera case makes a good example of the way the Mediterranean Sea has become naturally populated by Atlantic species after its re-connection to the ocean following the Messinian salinity crisis till the present.

\section{Rare species}

Three Sepiola species can be regarded as very rare, since each of them was only found in a very limited site, which coincides with its type locality. They are Sepiola aurantiaca, Sepiola bursadhaesa and Sepiola boletzkyi. The rarity of the latter two species may be just apparent because they were only recently described, hence they might have been overlooked if found in other district samples; in this respect, let us mention once more that members of Sepiolinae are the most difficult to identify species among the Mediterranean cephalopods especially when sexually immature.

As for Sepiola aurantiaca, the only known specimens were collected about one century ago exclusively in the spot called Amontatura, in the Gulf of Naples (Jatta, 1896). Until a few years ago, this sepioline had been reported in the eastern Atlantic Ocean as well, but Goud \& de Heij (2012) showed that the Atlantic specimens belong indeed to Sepiola pfefferi Grimpe, 1921, a sister species of Sepiola aurantiaca. The Mediterranean rarity of the latter sepioline is quite puzzling especially when one takes into account that the Gulf of Naples is possibly the best explored place in the Mediterranean Sea thanks to the workers at the Stazione Zoologica, including Giuseppe Jatta, the species discoverer, and Adolf Naef, the Sepiolidae reviser, both of them keen cephalopod collectors.

Among the comparatively rare species, one may mention Sepiola steenstrupiana. In fact, this sepioline has been found in all Mediterranean districts (Mangold \& Boletzky, 1987; Reid \& Jereb, 2005). Its deceptive rarity depends on the fact that it lives in coastal areas only, at very shallow depths which are poorly explored with the customary trawl nets. Moreover, strangely enough, Sepiola steenstrupi- 
ana has been reported from the Red Sea (Adam, 1973 ) and the western Indian Ocean (coasts of Somalia) (Rocha et al., 1998). This might be a rare case of counter-Lessepsian migration, from the Mediterranean to the Red Sea.

\section{GENERAL REMARKS}

In summary, updates for the Mediterranean Sepiolidae with respect to an earlier review of the Mediterranean teuthofauna (Bello, 2003) consist in: (a) the addition of the newly described species Sepiola bursadhaesa and Sepiola boletzkyi, one century after the mentioned discoveries by Naef (1912a, 1912b, 1912c; 1916); (b) evidence that Sepiola aurantiaca is endemic to this sea; (c) disclosure that Sepiola rondeletii is not widely dis- tributed in the NE Atlantic Ocean but just close to the Gibraltar Strait, hence it is a quasi-endemic species; (d) evidence that Sepiola ligulata lives also in the NE Atlantic Ocean (it was deemed quasi-endemic by Bello, 2003; see also Reid \& Jereb, 2005); (e) confirmation that Stoloteuthis leucoptera has established a viable population in the western basin. As for the Atlantic sepiolid diversity, in addition to the just conveyed news on Sepiola rondeletii and Sepiola ligulata: (f) a new species was described, namely Sepiola tridens; (g) Sepiola pfefferi was found to be the NE Atlantic sibling of the Mediterranean Sepiola aurantiaca.

As stated in Introduction, Sepiolidae is the most speciose cephalopod family in the Mediterranean (17 species) as well as in the NE Atlantic district (16 species); the overall NE Atlantic-Mediterranean

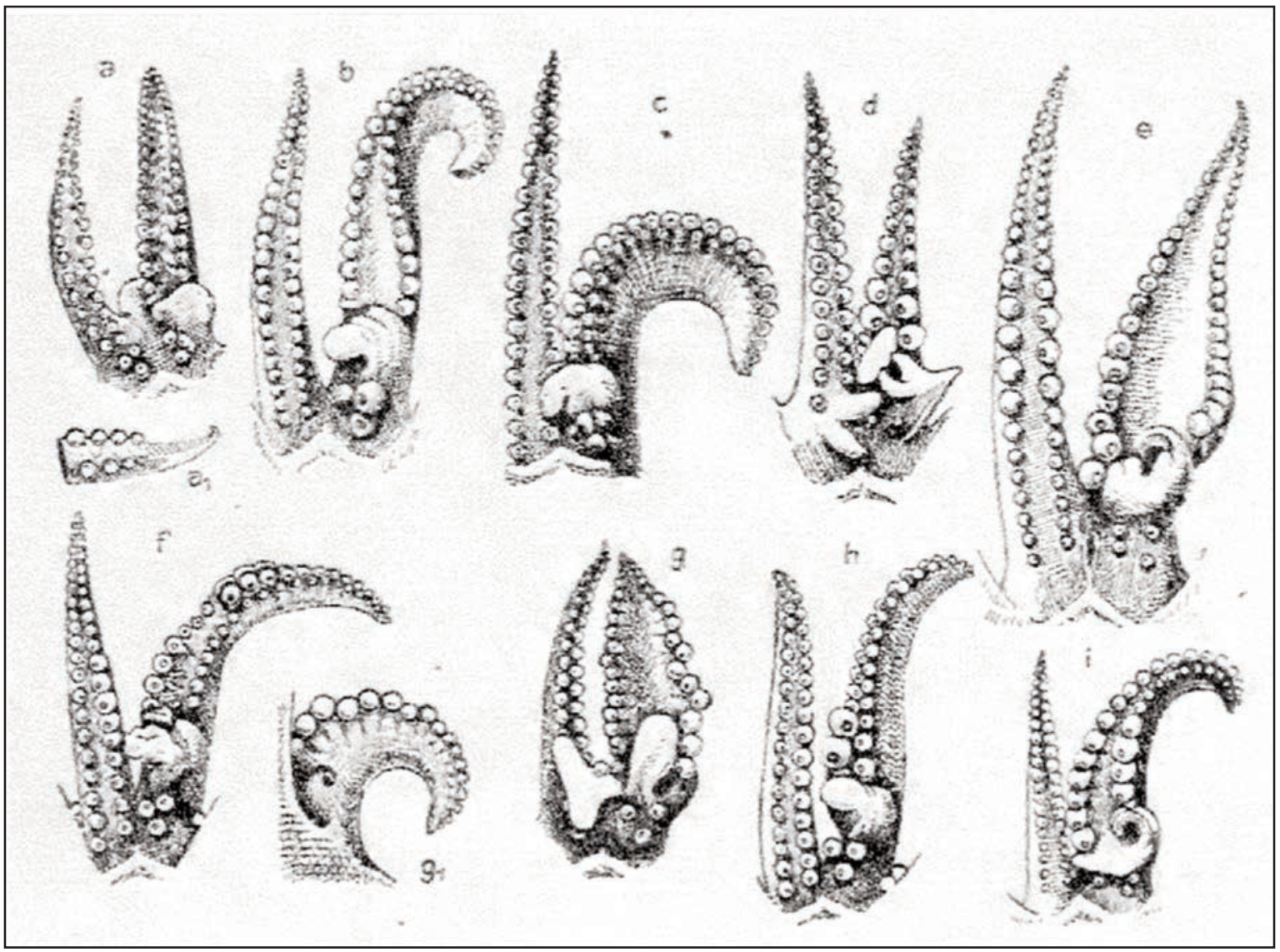

Figure 6. The hectocotylus diversity in many sepioline species (after Naef, 1912b: fig. 1). The drawings show the pair of dorsal arms - the hectocotylus is that on the right side - of Sepiola steenstrupiana, S. robusta, S. rondeletii, S. aurantiaca, Sepietta oweniana, S. atlantica, S. ligulata, S. intermedia, and Rondeletiola minor (left to right, starting from upper row). 


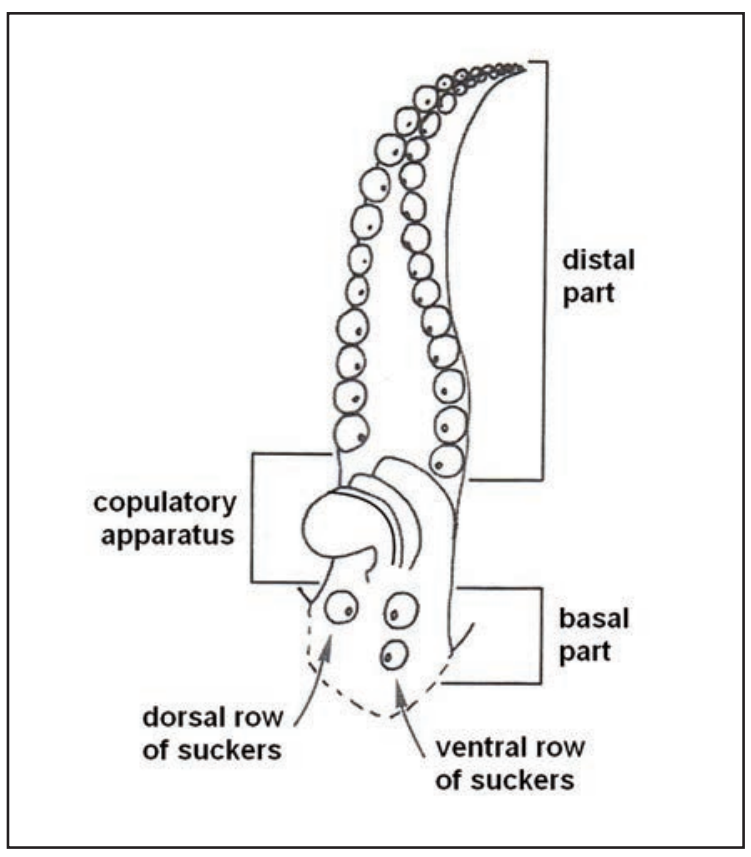

Figure 7. The hectocotylus basic type of the Sepiola atlantica group (sensu Naef, 1923). The copulatory apparatus is formed by four suckerless, elongate stalks fused with each other throughout their length into a structure apically directed and curled inwards; in some species the two dorsal suckers are not readily perceivable because of their strict fusion into a single tubercle.

sepiolid diversity includes 22 specific entities, 12 of which are shared by both districts (Table 1). The most speciose subfamily is Sepiolinae, which amounts to 13 specific entities in the Mediterranean, 10 in the NE Atlantic Ocean and overall 16, seven of which are found in both districts; in other words, this subfamily includes a fairly high fraction of endemic and quasi-endemic species: $69 \%$ in the Mediterranean Sea and 30\% in the NE Atlantic. On the contrary, the few Mediterranean species belonging to Rossiinae and Heteroteuthinae live also in the North Atlantic Ocean; the only two endemic species in the latter district, namely Rossia palpebrosa and Rossia moelleri, live in high latitudes, well north of the Strait of Gibraltar.

The NE Atlantic-Mediterranean Sepiolinae form a fairly compact clade, where Sepietta and Rondeletiola are sister genera, that is synthetically (Sepiola, Sepietta, Rondeletiola)) (Bello, 1998). The males in this clade are characterized by a peculiar hectocotylus - the male left dorsal arm modified into a copulatory organ - where the copulatory apparatus is made of four modified suckers, two ventral and two dorsal (additional modified dorsal suckers may occur in some species) (Naef, 1923; Bello, 1995); the modification consists in the loss of the sucker proper and lengthening and/or widening of the stalk (Fig. 6) (Naef, 1923; Bello, 1995). The females bear a unique feature, that is an apomorphic character: the bursa copulatrix (Fig. 2).

A closer look at Sepiolinae reveals a fairly high number of twin- and sister-species (the former species displaying a closer affinity with each other than the latter) (Table 2). The majority of the $\mathrm{Se}$ piola species, both Mediterranean and Atlantic, are gathered in the "atlantica group" sensu Naef (1923) because of their similarity (see also Bello, 2013) (Table 2). This group is characterized by the lengthening, fusion throughout their length, and inwards curling of the four modified sucker stalks of the copulatory apparatus (Fig. 7) (Naef, 1923; Bello, 2013). All of them are either Mediterranean endemics/quasi-endemics or NE Atlantic endemics, seven and two species respectively. Outside the "atlantica group", Sepiola aurantiaca and Sepiola pfefferi are twins and are endemic of the Mediterranean and the Atlantic Ocean respectively. The genus Sepietta contains fewer specific entities: a Mediterranean quasi-endemic, i.e. Sepiola obscura, and two widely distributed twin species, i.e. Sepiola oweniana and Sepiola neglecta.

\section{GENESIS OF THE MEDITERRANEAN SEPIOLIDAE DIVERSITY}

The Mediterranean Sea is generally deemed a sub-region of the Atlantic Ocean because its biodiversity originated with the Zanclean flood (5.3 MYA) following the Messinian salinity crisis (Blanc, 2002), which allowed the colonization by Atlantic organisms. The latter phenomenon has gone on since and is still at work; as for cephalopods, see for instance the above reported recent entrance and establishment of S. leucoptera in the western Mediterranean basin. One must point out that not all species entering the Mediterranean succeed in establishing a viable population here because the environmental conditions may be neither suitable for their survival nor for their reproduction (Bouchet \& Taviani, 1992). 


\begin{tabular}{|c|c|c|c|c|}
\hline GENERA & SPECIES & NE ATLANTIC & MEDITERRANEAN & NOTES \\
\hline \multirow[t]{9}{*}{ Sepiola (atlantica group) } & affinis & & $\mathrm{E}$ & 1 \\
\hline & atlantica & E & & 2 \\
\hline & boletzkyi & & E & \\
\hline & bursadhaesa & & $\mathrm{E}$ & \\
\hline & intermedia & $(+)$ & QE & \\
\hline & robusta & & E & \\
\hline & rondeletii & $(+)$ & QE & \\
\hline & steenstrupiana & & $\mathrm{E}$ & \\
\hline & tridens & E & & 2 \\
\hline \multirow[t]{3}{*}{ Sepiola (others) } & aurantiaca & & $\mathrm{E}$ & 3 \\
\hline & ligulata & + & + & \\
\hline & pfefferi & $\mathrm{E}$ & & 3 \\
\hline Rondeletiola & minor & + & + & \\
\hline \multirow[t]{3}{*}{ Sepietta } & neglecta & + & + & 4 \\
\hline & obscura & $(+)$ & $\mathrm{QE}$ & \\
\hline & oweniana & + & + & 4 \\
\hline Heteroteuthis & dispar & + & + & \\
\hline Stoloteuthis & leucoptera & + & + & 5 \\
\hline \multirow[t]{3}{*}{ Rossia } & macrosoma & + & + & \\
\hline & moelleri & E & & \\
\hline & palpebrosa & E & & \\
\hline Neorossia & caroli & + & + & \\
\hline
\end{tabular}

Table 1. Composition of the north-eastern Atlantic and Mediterranean sepiolid-faunas. E: endemic species; QE: quasi-endemic species (see text); +: occurring in large part of district; (+): occurring close to Gibraltar Strait. NOTES: (1) The species of Sepiola in the "atlantica group" are phylogenetically closely connected with each other, hence they are sister species (Naef, 1923; Bello, 2013); (2) atlantica and tridens are twin species (de Heij \& Goud, 2010); (3) pfefferi and aurantiaca are twin species (Goud \& de Heij, 2012); (4) oweniana and neglecta are sibling species (Bello, 1998); (5) nonindigenous species recently established in the western Mediterranean (Battaglia et al., 2011).

\begin{tabular}{|l|l|}
\hline MEDITERRANEAN SEA & NE ATLANTIC OCEAN \\
\hline Sepiola aurantiaca & Sepiola pfefferi \\
\hline $\begin{array}{l}\text { Sepiola atlantica group (affinis, boletzkyi, bursadhaesa, } \\
\text { intermedia, robusta, rondeletii, steenstrupiana) }\end{array}$ & Sepiola atlantica group (atlantica, tridens) \\
\hline
\end{tabular}

Table 2. Closely related NE Atlantic-Mediterranean pairs of Sepiola species. 
Incidentally, additional, albeit unnatural, comparatively recent sources for the Mediterranean colonization are the opening of the Suez Canal, on 17 November 1869 and living creatures carrying in ship ballast water. In consequence of the former, some 500 Red Sea organisms have crossed the canal to reach the Levant Sea and, in several instances, spread out across most Mediterranean waters (Galil et al., 2017); they include some cephalopods too, e.g. Sepioteuthis lessoniana (Teuthida Loliginidae) (Salman, 2002). The latter source, i.e. ballast water, was invoked by Orsi Relini (2009) to explain the Mediterranean occurrences of the Indo-Pacific Tremoctopus gracilis (Octopoda Tremoctopodidae).

The natural colonization of the Mediterranean, a medium-latitude sea, by Atlantic organisms was heavily shaped by the sequence of Pleistocene glaciations and interglaciations that brought into the Mediterranean cold and warm elements respectively (Taviani, 2003). This phenomenon is typified by the rossiines: Rossia macrosoma and Neorossia caroli are respectively of Mauretanic (i.e. warm) and Lusitanic (i.e. cold) affinity (classification according to Ekman,1953). Parenthetically, Bello (2003) suggested that in a pair of akin species the cold-water one inhabits deeper layers than the warm-water one; this supposition is backed up by the distributions of the above-mentioned pair of rossiines.

The above paragraph implies that the two species of Mediterranean Rossiinae came from the near Atlantic Ocean. The same is true for the two species of Mediterranean Heteroteuthinae, whose entrance was further favoured by their mode of life, pelagic for Heteroteuthis dispar and bentho-pelagic for Stoloteuthis leucoptera (Reid \& Jereb, 2005). The only NE Atlantic endemic species belonging to these two subfamilies live at high latitudes and most probably never moved southward to the level of the Strait of Gibraltar: Rossia palpebrosa is strictly temperate and Rossia moelleri is arctic (Reid \& Jereb, 2005).

In addition to the species coming from the Atlantic Ocean, many new entities originated in the Mediterranean by in situ speciation after its re-colonization by Atlantic organisms. This statement concerns all marine taxa and, as for cephalopods, is particularly true for Sepiolinae, which, differently from the co-familiar subfamilies, display a high de- gree of endemism especially in the genus Sepiola.

Endemic members of this genus are also found in the Atlantic Ocean, namely Sepiola atlantica, Sepiola tridens and Sepiola pfefferi (Table 1). Mediterranean Sepiola species have their twin or sister counterparts in the ocean (Table 2), with the only exception of Sepiola ligulata, which occurs in both districts. This peculiar distribution is robust evidence to corroborate the close affinity between Mediterranean and Atlantic sepiolines and to support the hypothesis that both the Atlantic and Mediterranean Sepiola species originated from Atlantic common ancestors - possibly one for pfefferi-aurantiaca, which are twin species (Goud \& de Heij, 2012), and another one for the "atlantica group" - that entered the Mediterranean and produced separate populations, which evolved independently to give rise to the present-day species. Moreover, some of the species that evolved in the Mediterranean basin went back through the Strait of Gibraltar and spread in its Atlantic vicinities, which species I termed quasi-endemic (Bello, 2003), namely Sepiola intermedia and Sepiola rondeletii. In particular, the situation of the "atlantica group" is quite interesting. As reported above, the members of this group share a peculiar hectocotylus, different from all other sepiolines. The examination and comparison of the hectocotylus of the "atlantica group" members show that its variations are just different expressions of a common protohectocotylus (proto- with respect to this group, not to the whole Sepiolinae) (Fig. 7).

As for the other genera in Sepiolinae, the species of Rondeletiola and Sepietta are found in both districts, although Sepiola obscura is a Mediterranean quasi-endemic, as reported above.

Two features appear of paramount importance in characterizing high-dispersal sepiolines (i.e. occurring in both the Atlantic Ocean and the Mediterranean) vs. low-dispersal species (endemic or quasi-endemic of either district): relative egg size (sensu Boletzky, 1974 and 1977) and, to a lesser extent, habitat depth. As shown by Boletzky (1974 and 1977), the egg relative size is responsible for the hatchling mode of life: the larger it is the shorter the planktonic life, hence less wide the spreading. In fact, the Sepiola species - all of which, with one exception, are endemic or quasiendemic of either district - reproduce by comparatively large eggs (Gabel-Deickert, 1995) and live 
mostly in shallow waters. The exception, namely Sepiola ligulata, though reproducing by large eggs, has been collected as deep as $350 \mathrm{~m}$. The other comparatively deep water Sepiola species, i.e. intermedia and robusta, are quasi-endemic. Rondeletiola and Sepietta, on the contrary, include comparatively small-egged, deep-living species, with the exception of Sepiola obscura, which is large-egged and lives in shallow waters (GabelDeickert, 1995). Accordingly $R$. minor, S. oweni$a n a$, and $S$. neglecta are widely spread in both the Atlantic Ocean and the Mediterranean Sea, whereas S. obscura, as stated above, is a Mediterranean quasi-endemic.

According to Bello (2003), the high rate speciation in Sepiolinae is due to the following features: small body size; short life cycle (less than a year); reduced number of eggs, hence reduced fecundity, with respect to other Mediterranean cephalopods (Gabel-Deickert, 1996); reproduction by large eggs, which give birth to benthic early juveniles (Boletzky, 1974 and 1977); nekto-benthic mode of life (Bello \& Biagi, 1995); mostly living in shallow coastal waters; fairly diverse hectocotylus, in males, and bursa copulatrix, in females (Naef, 1923; Bello, 1995). All these characteristics greatly favour speciation. For instance, the comparatively low-dispersal capabilities of both early juveniles and adults in shallow water habitats facilitates the establishment of small, marginal populations where the process of speciation may occur more efficiently (Eldredge \& Gould, 1972). In fact, a few Mediterranean Sepiola species seemingly have a restricted distribution, e.g. Sepiola aurantiaca and Sepiola bursadhaesa. Bello (2003) also stated that sepiolines living in littoral environments appear to fit fairly well the statement of Hutchinson (1959) in his Homage to Santa Rosalia: “... small size, by permitting animals to become specialized to the conditions offered by small diversified elements of the environmental mosaic, clearly makes possible a degree of diversity quite unknown among groups of larger organisms." (see Bello, 2003, for further comments). Moreover, a role in speciation is most probably also played by the species-specific lockand-key copulatory organs, i.e. the male hectocotylus and the female bursa copulatrix, which preventing hybridization among allied sympatric species reinforces reproduction isolation (Hutchinson, 1959). In recent times, the lock-and-key mech- anisms have been subjected to criticism and are no longer believed to depend on natural selection exclusively but rather on a combination of natural and sexual selection (Masly, 2012; Brennan \& Prum, 2015). Whatever the evolutionary driving forces behind this selection, we can at least safely state that the species-specific hectocotylus-bursa copulatrix pairs in the Sepiolinae are the result of coevolutionary processes.

\section{CONCLUSIONS}

We presently have at our disposal a fairly satisfactory picture of the systematics and biogeography of Mediterranean Sepiolidae, but there is still much to learn.

First of all, it must be stressed that, sadly enough, the literature is still crowded with misidentifications of sepioline specimens, including those used in genetic research (Groenenberg et al., 2009), which hinders the understanding of both their phylogenetic relationships and distribution, geographical as well as bathymetrical. Therefore, a prudent approach is suggested to workers dealing with sepiolid identification; on this respect a fair solution is the deposit of voucher specimens in official collections.

For a worldwide view, the phylogenetic relationships of the Atlantic-Mediterranean Sepiolidae with co-familiar members from the other oceans need to be studied on the basis of both morphological and genetic accounts. In turn, the ocean-wide biogeography of the family should be analyzed. This way, further light would also be shed on the Mediterranean situation of Sepiolidae.

\section{REFERENCES}

Adam W., 1973. Cephalopods from the Red Sea. Contributions to the Knowledge of the Red Sea, 47: 9-47.

Allcock A.L., Lindgren A. \& Strugnell J.M., 2014. The contribution of molecular data to our understanding of cephalopod evolution and systematics: a review. Journal of Natural History, 49: 1373-1421. https:// doi.org/10.1080/00222933.2013.825342

Battaglia P., Bello G., Chemello R., Giacobbe S., Jereb P., Russo G. \& Scotti G., 2011. Stoloteuthis leucoptera (Verrill, 1878). In: Andaloro F., Identificazione e distribuzione nei mari italiani di specie non 
indigene. Atlante delle specie non indigene nei mari italiani e nel Mediterraneo. ISPRA, Ministero dell'Ambiente, Si.Di.Mar., Roma: www.medalien.isprambiente.it.

Bello G., 1995. A key for the identification of the Mediterranean sepiolids (Mollusca: Cephalopoda). Bulletin de 1'Institut océanographique, Monaco, $\mathrm{n}^{\circ}$ spécial 16: 41-55.

Bello G., 1998. Cladistic analysis of the Atlanto-Mediterranean sepiolines (Cephalopoda: Sepiolidae) based on morphological characters. Memorie del Museo Civico di Storia Naturale di Verona ( $2^{\mathrm{a}}$ serie), Sezione Scienze della Vita, 13: 81-85.

Bello G., 1999. Cephalopods in the diet of albacore, Thunnus alalunga, from the Adriatic Sea. Journal of Molluscan Studies, 65: 233-240. https:// doi.org/10. 1093/mollus/65.2.233

Bello G., 2003. The biogeography of Mediterranean cephalopods. Biogeographia, 24: 209-226.

Bello G., 2008. Cephalopoda. In: Relini G. (Ed.), Checklist della flora e della fauna dei mari italiani. Biologia Marina Mediterranea, 15 (suppl. 1): 318-322.

Bello G., 2013. Description of a new sepioline species, Sepiola bursadhaesa n. sp. (Cephalopoda: Sepiolidae), from the Catalan Sea, with remarks and identication key for the Sepiola atlantica group. Scientia Marina, 77: 489-499. https:// doi.org/10.3989/scimar. 03720.31A

Bello G., 2015. The original descriptions of the Mediterranean taxa in the order Sepiolida (Mollusca: Cephalopoda) with notes on the validity of the specific name Sepiola rondeletii Leach, 1817. Bollettino Malacologico, 51: 22-46.

Bello G., 2017. Cephalopoda (aggiornamento dicembre 2016 / update December 2016). In: Relini G. (Ed.), Checklist della flora e della fauna dei mari italiani. Biologia Marina Mediterranea / web:http://www. sibm.it/CHECKLIST/cefalopoda\%20aggiornamento\%20 2017\%20def.pdf.

Bello G. \& Biagi V., 1995. How benthic are sepiolids? Bulletin de l'Institut océanographique, Monaco, $\mathrm{n}^{\circ}$ spécial 16: 57-61.

Bello G. \& Salman A., 2015. Description of a new sepioline species, Sepiola boletzkyi n. sp. (Cephalopoda: Sepiolidae), from the Aegean Sea. European Journal of Taxonomy, 144: 1-12. https:// doi.org/10.5852/ejt. 2015.144

Blanc P.L., 2002. The opening of the Plio-Quaternary Gibraltar Strait: assessing the size of a cataclysm. Geodinamica Acta, 15: 303-317. https://doi.org/10. 1080/09853111.2002.10510763

Boletzky S.V., 1974. The "larvae" of Cephalopoda: a review. Thalassia Jugoslavica, 10: 45-76

Boletzky S.V., 1977. Post-hatching behavior and mode of life in cephalopods. Symposia of the Zoological Society of London, 38: 557-567.
Bouchet P. \& Taviani M., 1992. The Mediterranean deepsea fauna: pseudopopulations of Atlantic species? Deep Sea Research, Part A, 39: 169-184.

Brennan P.L.R. \& Prum R.O., 2015. Mechanisms and evidence of genital coevolution: the roles of natural selection, mate choice, and sexual conflict. Cold Spring Harbor Perspectives in Biology, 7: a0177749. https:// doi.org/10.1101/cshperspect.a017749.

Cuccu D., Mereu M., Masala P., Cau A. \& Jereb P., 2010. First record of Stoloteuthis leucoptera (Cephalopoda: Sepiolidae) in the Sardinian waters. Biologia Marina Mediterranea, 17: 334-335.

Delle Chiaje S., 1830. Memorie sulla storia e notomia degli animali senza vertebre del Regno di Napoli (Figure). [Società Tipografica], Napoli, LXX- $\neg$ CIX plts.

Dieuzeide R., 1959. Le fond chalutable à $600 \mathrm{~m}$ par le travers de Castiglione. La facies à Isidella elongata Esper. Station d'Aquiculture et de Pêche de Castiglione, n.s., 10: 71-75.

Ekman S., 1953. Zoogeography of the Sea. Sidgwick \& Jackson, London, xiv+417 pp.

Eldredge N. \& Gould S.J., 1972. Punctuated equilibria: an alternative to phyletic gradualism. In: Schopf T.J.M., Models in palaeobiology. Freeman, Cooper and Co., San Francisco: 82-115.

Gabel-Deickert A., 1995. Reproductive patterns in Sepiola affinis and other Sepiolidae (Mollusca, Cephalopoda). Bulletin de l'Institut océanographique, Monaco, $n^{\circ}$ spécial 16: 73-83.

Gabel-Deickert A., 1996. Fortpflanzung und Oozytenreifung von Sepiola affinis und anderen Sepiolidae (Mollusca: Cephalopoda). Doctoral Thesis, Freie Universität Berlin, 203+lx pp.

Galil B., Marchini A., Occhipinti-Ambrogi A. \& Ojaveer H., 2017. The enlargement of the Suez Canal - Erythraean introductions and management challenges. Management of Biological Invasions, 8: 141-152. https://doi.org/10.3391/mbi.2017.8.2.02

Giordano D. \& Carbonara P., 1999. Nota sulla distribuzione dei molluschi cefalopodi nel Tirreno Centro-Meridionale. Biologia Marina Mediterranea, 6: 573-575.

Golikov A.V., Sabirov R.M., Lubin P.A., Jørgensen L.L. \& Beck I.M., 2014. The northernmost record of Sepietta oweniana (Cephalopoda: Sepiolidae) and comments on boreo-subtropical cephalopod species occurrence in the Arctic. Marine Biodiversity Records, 7: e58. https://doi.org/10.1017/S175526721 4000645

Goud J. \& de Heij A., 2012. Mediterranean Sepiola aurantiaca Jatta, 1896, versus the NE Atlantic Sepiola pfefferi Grimpe, 1921 (Cephalopoda, Sepiolinae). Basteria, 76: 1-11.

Groenenberg D.S.J., Goud J., de Heij A. \& Gittenberger E., 2009. Molecular phylogeny of North Sea Sepioli- 
nae (Cephalopoda: Sepiolidae) reveals an overlooked Sepiola species. Journal of Molluscan Studies, 75: 361-369. https://doi.org/10.1093/mollus/eyp 032

Guerra A., 1982. Cefalópodos capturados en la campaña "Golfo de Cádiz-81". Resultados de Expediciones Científicas del B/O Cornide, 10: 17-49.

Guerra A., 1986. Sepiolinae (Mollusca, Cephalopoda) de la ría de Vigo. Iberus, 6: 175-184.

Guerra A., 1992. Mollusca, Cephalopoda. Fauna Ibérica, Museo Nacional de Ciencias Naturales. CSIC, Madrid, vol. 1, 327 pp., 12 plts.

Heij A. de \& Goud J., 2010. Sepiola tridens spec. nov., an overlooked species (Cephalopoda: Sepiolidae) living in the North Sea and north-eastern Atlantic Ocean. Basteria, 74: 51-62.

Heij A. de Goud J. \& Martin J., 2017. The distribution of Sepiolidae (Cephalopoda) in the Northeast Atlantic Ocean. Basteria, 81: 37-50.

Hutchinson G.E., 1959. Homage to Santa Rosalia or Why there are so many kinds of animals? The American Naturalist, 93: 145-159.

Jatta G., 1896. I Cefalopodi viventi nel Golfo di Napoli. (Sistematica). Fauna und Flora des Golfes von Neapel, 23: xxi+268 pp.; 31 plts.

Joubin L., 1902. Révision des Sepiolidae. Mémoires, Société Zoologique de France, 15: 80-145.

Leach W.E., 1817. Synopsis of the Orders, Families, and Genera of the Class Cephalopoda. The Zoological Miscellany, 3: 137-141.

Levy F., 1912. Observations sur les Sépioles des côtes de France. Archives de Zoologie Expérimentale et Générale, 5e sér., 9, Notes et Revue LIV-LIX.

Mangold K. \& Boletzky S.V., 1987. Céphalopodes. Fiches FAO d'identication des espèces pour les besoins de la pêche. (Révision 1). Méditerranée et Mer Noire. FAO, Rome: 633-714.

Masly J.P., 2012. 170 years of "lock-and-key": genital morphology and reproductive isolation. International Journal of Evolutionary Biology, Article ID 247352, 10 pages. http://dx.doi.org/10.1155/2012/247352

MolluscaBase, 2018. Heteroteuthis atantis Voss, 1955. Accessed through: World Register of Marine Species at: $\quad$ http://www.marinespecies.org /aphia.php? $\mathrm{p}=$ taxdetails\&id=579011 28.3.2018.

Naef A., 1912a. Teuthologische Notizen. 1. Die Familien der Myopsiden; 2. Die Gattungen der Sepioliden. Zoologische Anzeicher, 39: 241-248.

Naef A., 1912b. Teuthologische Notizen. 3. Die Arten der Gattungen Sepiola und Sepietta. Zoologischer Anzeiger, 39: 262-271.

Naef A., 1912c. Teuthologische Notizen. 7. Zur Morphologie und Systematik der Sepiola und SepiettaArten. Zoologischer Anzeiger, 40: 78-85.

Naef A., 1916. Ueber neue Sepioliden aus dem Golf von
Neapel. Pubblicazioni della Stazione Zoologica di Napoli, 1: 1-10.

Naef A., 1923. Die Cephalopoden. Fauna und Flora des Golfes von Neapel, 35: 1-863. [English translation by A. Mercado, 1972; Smithsonian Institution, Washington D.C.: 917 pp.]

Nesis K.N., 1987. Cephalopods of the world. T.F.H. Publication, Neptune City, N.J., 351 pp.

Nesis K., 1993. Cephalopods of seamounts and submarine ridges. In: Okutani, T., O’Dor, R.K., Kubodera, T., Recent Advances in Cephalopod Fisheries Biology. Tokai University Press, Tokyo: 365-374.

Olmos-Pérez L., Roura Á., Pierce G.J. \& Gonzáles Á.F., 2018. Sepiolid paralarval diversity in a regional upwelling area of the NE Atlantic. Hydrobiologia, 808: 57-70. https://doi.org/10.1007/s10750-0173186-3

Orsi Relini L., 2009. Notes about colour display observed in female specimens of Tremoctopus (Cephalopoda: Octopoda) and their taxonomic value. Bollettino Malacologico, 45 (suppl.): 13-16.

Orsi Relini L. \& Massi D., 1991. The butterfly squid Stoloteuthis leucoptera in the Mediterranean. Journal of the Marine Biological Association of the United Kingdom, 71: 47-51.

Pfeffer G., 1908. Cephalopoden. Nordisches Plankton. Zweiter Band: Tunicata, Mollusca, 4: 9-116.

Quetglas A., Ordines F., González M., Zaragoza N., Mallol S., Valls M. \& De Mesa A., 2013. Uncommon pelagic and deep-sea cephalopods in the Mediterranean: new data and literature review. Mediterranean Marine Science, 14: 69-85. http://dx.doi.org/10.12681/mms. 320

Reid A. \& Jereb P., 2005. Family Sepiolidae. In: Jereb P. $\&$ Roper C.F.E., Cephalopods of the world. An annotated and illustrated catalogue of species known to date. Vol. 1. FAO Species Catalogue for Fishery Purposes, 4: 153-203.

Rocha F., Fuentes L., Guerra A. \& Sainza M.C., 1998. Cephalopods of Somalia. Iberus, 16: 129-142.

Rosa R., Pissarra V., Borges F.O., Xavier J., Gleadall I.G., Golikov A., Bello G., Morais L., Lishchenko F., Roura Á., Judkins H., Ibáñez C.M., Piatkowski U., Vecchione M. \& Villanueva R., 2019. Global patterns of species richness in coastal cephalopods. Frontiers in Marine Science, 6: 469; http://dx.doi.org/10.3389/ fmars.2019.00469.

Rüppell E., 1844. Intorno ad alcuni cefalopodi del mare di Messina. Lettera del Dr. Eduardo Rüppell di Frankfurt sul Meno al Prof. Anastasio Cocco. Giornale del Gabinetto Letterario di Messina, 5: 129-135.

Salman A., 2002. New report of the loliginid squid Sepioteuthis lessoniana Lesson, 1830 in the Mediterranean. Israel Journal of Zoology, 48: 249-250.

Sánchez P., Belcari P. \& Sartor P., 1998. Composition and 
spatial distribution of cephalopods in two north-western Mediterranean areas. South African Journal of marine Science, 20: 17-24.

Sweeney M.J., 2001. Current Classification of Recent Cephalopoda. Washington DC., National Museum of Natural History, www.mnh.si.edu/ cephs/newclass. pdf [accessed 4.2.2011].

Taviani M., 2003. Shaping the biogeography of the Mediterranean basin: a geologist's perspective. Biogeography, 24: 15-21.

Volpi C., Borri M. \& Zucchi A., 1995. Notes on the family Sepiolidae (Mollusca, Cephalopoda) off the Northern Tuscany coast. Bulletin de 1'Institut océanographique, Monaco, $\mathrm{n}^{\circ}$ special 16: 27-34.

Voss G.L., 1955. The Cephalopoda Obtained by the Harvard-Havana Expedition off the Coast of Cuba in 1938-39. Bulletin of Marine Science of the Gulf and Caribbean, 5: 81-115.

Würtz M., Matricardi G. \& Repetto N., 1995. Sepiolidae
(Mollusca: Cephalopoda) from the lower Tyrrhenian Sea, central Mediterranean. Bulletin de l'Institut océanographique, Monaco, $\mathrm{n}^{\circ}$ special 16: 35-39.

Young R.E., 2007. Sepiolidae Leach 1817. Version 26 December 2007 (under construction). The Tree of Life Web Project: http://tolweb.org/Sepiolidae/ 19988/2007.12.26 [accessed 1.6.2015].

Young R.E., Roper C.F.E \& Vecchione M., 2015. Heteroteuthinae Appellof, 1898. Version 06 July 2014 (under construction). The Tree of Life Web Project: http://tolweb.org/ Heteroteuthinae/20027/2015.11.04 [accessed 19.10.2018].

Young R.E. \& Vecchione M., 2014. Rossiinae Appellof, 1898. Version 04 November 2015 (under construction). The Tree of Life Web Project: http://tolweb.org/Rossiinae/20023/2014.07.06 [accessed 19.10.2018]. 